\title{
Diet and trophic structure of the fish fauna in a subtropical ecosystem: impoundment effects
}

\author{
Rosilene Luciana Delariva ${ }^{1}$, Norma Segatti Hahn² \\ and Elaine Antoniassi Luiz Kashiwaqui ${ }^{3}$
}

This study examined the diet and trophic structure of the fish fauna, over temporal and spatial scales, as affected by the impoundment of the Iguaçu River in the region of Salto Caxias, Paraná State, Brazil. Sampling was conducted before (March 1997 - February 1998) and after the impoundment (March 1999 - February 2000), at four sampling sites. The stomach contents were analyzed by the volumetric method. The species could be organized in 10 trophic guilds: algivores, carcinophages, detritivores, herbivores, aquatic insectivores, terrestrial insectivores, invertivores, omnivores, piscivores, and planktivores; the first and last guilds were represented only in the post-impoundment period. Similarity patterns and feeding changes were summarized by a non-metric Multi-dimensional Scaling (nMDS) analysis and statistically tested by a Permutational multivariate analysis of variance (PERMANOVA). Most species showed feeding changes, except for the piscivores and detritivores. These changes were related to the temporal factor (impoundment phases), such as reduced intake of benthic organisms and allochthonous food, which were usually replaced by resources from the reservoir itself (algae, microcrustaceans, and fish), simplifying the food spectrum of the fish fauna. A different indicator of food resources (IndVal) corroborated these changes in the feeding of the species. The proportions of the trophic guilds evaluated based on the catch per unit of effort (CPUE) and tested by ANOSIM were significantly different before and after the impoundment. Herbivores and piscivores were the guilds that contributed (SIMPER) to these differences, especially the high increase in biomass of the piscivore guild after the impoundment. Variations in the abundance of trophic guilds were more directly related to changes in the feeding habits of the fish fauna than to increases in the number and biomass of the species that constitute these guilds.

Neste estudo foram avaliadas a dieta e a estrutura trófica da ictiofauna em escala temporal e espacial, sob efeito do represamento do rio Iguaçu, na região de Salto Caxias, Paraná, Brasil. Para tanto, foram realizadas amostragens nas fases pré (março/97 a fevereiro/98) e pós represamento (março/99 a fevereiro/00) em quatro pontos de coleta. Os conteúdos estomacais foram avaliados pelo método volumétrico. As espécies foram organizadas em 10 guildas tróficas: algívora, carcinófaga, detritívora, herbívora, insetívora aquática, insetívora terrestre, invertívora, omnívora, piscívora e planctívora, sendo a primeira e a última representadas apenas após o represamento. Os padrões de similaridade e alterações na dieta foram sintetizados através da ordenação multidimensional não paramétrica (nMDS) e estatisticamente testados pela análise de variância permutacional (PERMANOVA). Foram constatadas alterações na dieta da maioria das espécies, com exceção das piscívoras e detritívoras. Essas alterações foram relacionadas ao fator temporal (fases do represamento), configuradas como redução no consumo de organismos bentônicos e alimentos alóctones, os quais foram geralmente substituídos por recursos provenientes do próprio ambiente (algas, microcrustáceos e peixes), simplificando o espectro alimentar. Diferentes recursos alimentares indicadores (IndVal) corroboram essas alterações na composição alimentar das espécies antes e após o represamento. As proporções na abundância (número e biomassa) das guildas tróficas avaliadas com base na captura por unidade de esforço (CPUE) e testadas pela ANOSIM foram significativamente diferentes antes e após o represamento. As guildas herbívora e piscívora foram as que mais contribuíram (SIMPER) para essas diferenças, especialmente o elevado incremento em biomassa da guilda piscívora após o represamento. As variações na abundância das guildas tróficas foram mais relacionadas às alterações no hábito alimentar da fauna de peixes, do que propriamente aos incrementos em número e em biomassa das espécies que anteriormente compunham tais guildas.

Key words: Feeding, Guilds, Iguaçu River, Reservoir, Temporal changes.

\footnotetext{
${ }^{1}$ Universidade Estadual do Oeste do Paraná, Centro de Ciências Biológicas e da Saúde. Rua Universitária 2069, Caixa Postal 711, 85819110 Cascavel, PR, Brazil. rosilene.delariva@unioeste.br

${ }^{2}$ Universidade Estadual de Maringá, Nupélia, Núcleo de Pesquisas em Limnologia, Ictiologia e Aquicultura. Av. Colombo, 5790, 87020-

900 Maringá, PR, Brazil. hahnns@nupelia.uem.br

${ }^{3}$ Universidade Estadual de Mato Grosso do Sul, GEAMBE, Grupo de Estudos em Ciências Ambientais e Educação, BR-163, km 20.2;

Mundo Novo, Mato Grosso do Sul. GETECH/UNIOESTE, Rua da Faculdade, 85903-000 Toledo, PR, Brazil. elainealk@uems.br
} 


\section{Introduction}

Impoundments are important agents in the reorganization of aquatic communities, and their consequences vary along a longitudinal gradient, with different effects on community structure (Agostinho et al., 2007). Studies of aquatic communities have indicated that the hydrological disturbances resulting from the impoundments are key elements in the reorganization of the local fish assemblages (Agostinho et al., 2008). One of the factors that limit the establishment and initial accommodation of the fish fauna in the new environment is the food supply (Mérona \& Vigouroux, 2012). The rapid changes from the flooding and new flow conditions change the diet and the trophic structure of the fish fauna, which may lead to the proliferation of some species and the disappearance of others (Piana et al., 2005; Hahn \& Fugi, 2007; Agostinho et al., 2010; Bennemann et al., 2011).

Historically, impoundments have altered the landscape of most rivers worldwide (Alexandre \& Almeida, 2010). In Brazil this situation is even more pronounced, due to the wide use of hydroelectric power and the increasing demand for energy (Agostinho et al., 2007; Barletta et al., 2010), and only a few rivers have remained in their natural state. In this country, the impoundments are concentrated in the south and southeast regions, and the main water courses of these regions now consist of cascades of reservoirs (Agostinho et al., 2008).

The impacts of damming are stronger on endemic fish faunas (Liermann et al., 2012), which are very common in rivers with a steep slope and numerous waterfalls, conditions that lead naturally to geographic isolation (Dias et al., 2012). This is the case of the Iguaçu River basin; this sub-basin was isolated from the Paraná River 22 million years ago by the Iguaçu Falls, which served as an effective barrier to the dispersal of fish species (Alcaraz et al., 2009). A high degree of endemism (around 70\%) (Baumgartner et al., 2012) and the absence of many families of fish that are common in the Paraná River basin are typical features of the Iguaçu basin (Garavello et al., 1997; Júlio Jr. et al., 1997). Changes in riverine habitats caused by human activities may lead to a risk of mass extinction, in this case at the global scale (Baumgartner et al., 2012).

Although several large reservoirs have been constructed in Brazil, $80 \%$ of them since 1960 , most studies in these environments were carried out only after the environment had changed, limiting the available information about the resulting impacts (Fièvet et al., 2001; Júlio Jr. et al., 2005; Agostinho et al., 2007). The number of publications concerning these impacts on the diet and trophic structure of fish fauna has increased in recent years (see Hahn \& Fugi, 2007). Nevertheless, most of the reports are limited and do not treat the entire fish fauna. In this sense, the challenge for research in this area is to obtain enough samples to make valid inferences.

The present study assessed the fish fauna of the Iguaçu River, Iguaçu River basin, according to food use, before and after the construction of Salto Caxias Dam. We are based on the hypothesis that abrupt changes in physical, chemical and habitat conditions caused by the impoundment alter the availability of food resources. We predict changes in the diets of the fish fauna as a result of the initial impacts from the impoundment, and consequently changes in the trophic structure (number and biomass) of the fish assemblage, on both temporal and spatial scales.

\section{Material and Methods}

\section{Study area}

The Iguaçu River has the largest watershed in Paraná State, with an area of approximately $72,000 \mathrm{~km}^{2}$. The river flows for about $1,060 \mathrm{~km}$ from its headwaters on the western slope of the Serra do Mar, near the city of Curitiba, until it joins the Paraná River. Similarly to other tributaries of the Paraná River, it is a geologically old river that runs from east to west (Maack, 1981).

The original terrain changed markedly in altitude along the course of the river, with a vertical drop from $830 \mathrm{~m}$ a.s.l. to $78 \mathrm{~m}$ at the outlet in the Paraná River. However, large impoundments constructed along the Iguaçu River in the last 30 years have converted the rapids and waterfalls between União da Vitória city (PR) and the Salto Osório waterfall into a cascade of five reservoirs that flood $515 \mathrm{~km}^{2}$ and store about $18.8 \times 10^{6} \mathrm{~m}^{3}$ water (Júlio Jr. et al., 1997). Salto Caxias is the fifth and last reservoir of this sequence. The dam was closed in October 1998, and the reservoir filled in four months. The reservoir covers $131 \mathrm{~km}^{2}$ of flooded area, is about $20 \mathrm{~m}$ deep, and the dam is $67 \mathrm{~m}$ high.

For this study, samples were taken before and after the impoundment of the Salto Caxias Reservoir, at four sampling sites: upstream (site 1 - below the mouth of the Chopim River), in the middle region (site 2 - middle part of the stretch analyzed), close to the dam (site 3 - Salto Caxias Dam), and downstream (site 4 - downstream from Salto Caxias Dam) (Fig. 1).

\section{Sampling}

Samples were taken monthly from March 1997 through February 1998 (before the impoundment) and quarterly from March 1999 through February 2000 (after the impoundment), using gill nets (mesh sizes from 3.0 to $16.0 \mathrm{~cm}$ between opposite knots, 12 simple nets and 3 trammel nets) set near the left and right banks for $24 \mathrm{~h}$, with inspections at dawn, dusk, and during the night. 


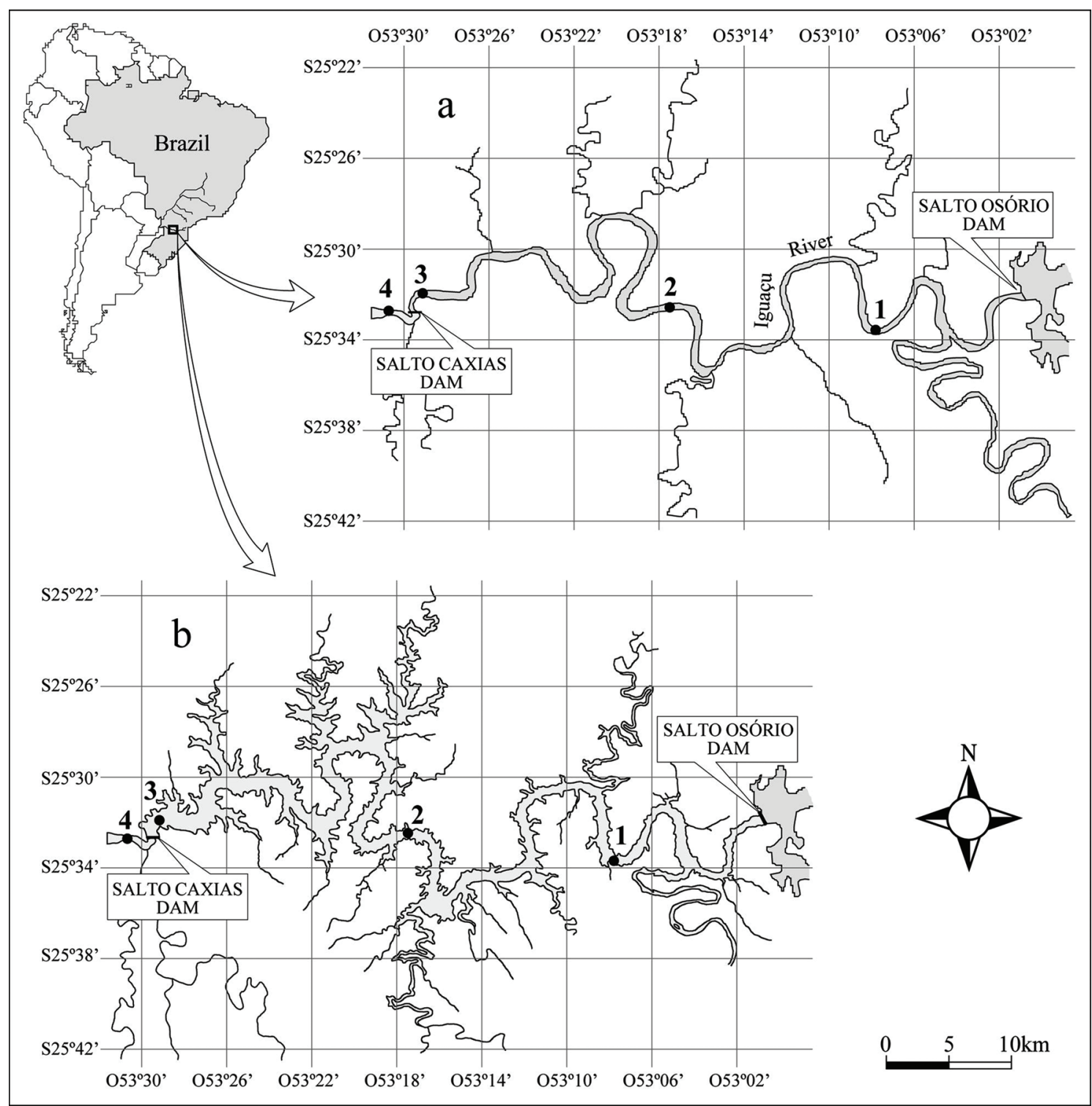

Fig. 1. Location of sampling sites along the longitudinal gradient of the Iguaçu River, in the area influenced by the Salto Caxias Reservoir, Paraná State. a) before the impoundment; b) after the impoundment. (site 1 = upstream; site $2=$ middle region; site $3=$ dam; site $4=$ downstream).

\section{Laboratory procedures}

Fish were identified by taxonomists, and voucher specimens (Table 1) were deposited in the Fish Collection of Nupélia (UEM/Maringá). After identification, specimens were measured (total length), weighed (total weight) and gutted; stomachs containing food were fixed in $4 \%$ formalin and later transferred to $70 \%$ ethanol. The stomach contents were examined to identify food items under a stereomicroscope and optical microscope. The contents were measured by the volumetric method (Hyslop, 1980): the total volume of a food item taken by the fish population is given as a percentage of the total volume of all stomach contents, estimated using graduated test tubes and a glass counting plate (Hellawell \& Abel, 1971). For species with an undifferentiated stomach (Loricariidae), the contents of the anterior third of the digestive tube were examined. For the analysis of stomach contents, we used only species for which we had at least five stomachs in total.

\section{Data analysis}

Food items were pooled into broader categories, designated as food resources, consisting of: detritus/sediment (particulate organic matter in different stages of decomposition and with mineral particles present), algae (filamentous and unicellular), terrestrial plants (fruit, seeds and leaves of vascular plants), aquatic plants (bryophytes), fish (muscle, fin rays, and whole fish), terrestrial insects (Coleoptera, Hemiptera, Hymenoptera, 
Isoptera, and Orthoptera), aquatic insects (Coleoptera, Diptera, Ephemeroptera, Megaloptera, Odonata, Plecoptera, Trichoptera), decapods (fragments and whole individuals of the crab Aegla sp.), microcrustaceans (Copepoda and Cladocera, especially planktonic species), macroinvertebrates (Arachnida, Bivalvia, Gastropoda, Annelida, and Diplopoda) and microinvertebrates (Testacea, Porifera, Rotifera, Bryozoa, Nematoda, Ostracoda).

Trophic guilds were determined from the matrix of stomach contents in each sampling site and phase by an adapted stepwise procedure of Mérona et al. (2001): Step 1: more than $50 \%$ detritus/sediment in the stomachs: detritivores; Step 2: more than $50 \%$ algae in the stomach: algivores; Step 3: more than $50 \%$ plant material (supplemented with algae and little proportion or absence of detritus) in the stomachs: herbivores; Step 4: more than 50\% plankton in the stomachs: planktivores; Step 5: more than 50\% aquatic insects in the stomachs: aquatic insectivores; Step 6: more than 50\% terrestrial insects in the stomachs: terrestrial insectivores; Step 7: more than $50 \%$ decapods in the stomachs: carcinophages; Step 8: more than $50 \%$ or by adding various invertebrates in the stomachs: invertivores; Step 9: more than 50\% fish (including scales) in the stomachs: piscivores; Step 10: none of the above statements and adding items of plant and animal origins: omnivores.

To identify trophic patterns and use of food resources by the fish fauna, we used nonmetric multidimensional scaling (nMDS; Kruskal, 1964). The Bray-Curtis index was applied to the matrix of volumetric abundance of food resource, transformed by square root. We obtained a confidence index (Stress) which determines the degree of proximity of the graphical representation to the real data. Stress values below 0.20 allow potential two-dimensional (2D) use of the nMDS (Clarke \& Warwick, 2001). Data were randomized 100 times, and the stability criterion was 0.005 standard deviations in the stress after 100 iterations.

To test the null hypothesis of no difference in diet composition of the fish assemblages among sites and periods (spatial and temporal factors) summarized by the nMDS (distance matrix), we used a Permutational Multivariate Analysis of Variance (PERMANOVA - Bray-Curtis index obtained with 9999 random permutations), a nonparametric method to test for multivariate differences among predefined groups (Anderson, 2001). PERMANOVA is sensitive to differences in multivariate dispersion, so we can check if dispersions are significantly different. To estimate the significance of this statistic, we used a Monte Carlo test with 10,000 permutations.

The indicator value method (IndVal) (Dufrêne \& Legendre, 1997) was employed to detect what food resources were indicative of the diet of the fish fauna before and after the impoundment. An IndVal is based on specificity (the relative
Table 1. List of fish species from the Iguaçu River in the area influenced by the Salto Caxias Reservoir, Paraná State. Voucher specimens: Number of voucher lots deposited in the Fish Collection of Nupélia (UEM/Maringá).

\begin{tabular}{|c|c|}
\hline Species & Voucher Specimens \\
\hline Apareiodon vittatus Garavello, 1977 & NUP 720; NUP 2049; NUP 2070 \\
\hline $\begin{array}{l}\text { Astyanax altiparanae Garutti \& } \\
\text { Britski, } 2000\end{array}$ & NUP 2452; NUP 6843 \\
\hline $\begin{array}{l}\text { Astyanax bifasciatus Garavello \& } \\
\text { Sampaio, } 2010\end{array}$ & NUP 2457 \\
\hline $\begin{array}{l}\text { Astyanax dissimilis Garavello \& } \\
\text { Sampaio, } 2010\end{array}$ & NUP 6872; NUP 1633 \\
\hline $\begin{array}{l}\text { Astyanax gymnodontus (Eigenmann, } \\
\text { 1911) }\end{array}$ & NUP 2050 \\
\hline $\begin{array}{l}\text { Astyanax minor Garavello \& } \\
\text { Sampaio, } 2010\end{array}$ & NUP 7296; NUP 6873 \\
\hline $\begin{array}{l}\text { Bryconamericus ikaa Casciotta, } \\
\text { Almirón \& Azpelicueta, } 2004\end{array}$ & NUP 2075 \\
\hline $\begin{array}{l}\text { Corydoras aff. paleatus (Jenyns, } \\
1842 \text { ) }\end{array}$ & NUP 709; NUP 5763 \\
\hline $\begin{array}{l}\text { Crenicichla iguassuensis Haseman, } \\
1911\end{array}$ & NUP 1788 \\
\hline Crenicichla sp. 2 & NUP 1642 \\
\hline $\begin{array}{l}\text { Cyanocharax aff. alburnus (Hensel, } \\
1870 \text { ) }\end{array}$ & NUP 6620; NUP 7248 \\
\hline $\begin{array}{l}\text { Cyphocharax cf. santacatarinae } \\
\text { (Fernández-Yépez, 1948) }\end{array}$ & NUP 1609 \\
\hline $\begin{array}{l}\text { Geophagus brasiliensis (Quoy \& } \\
\text { Gaimard, 1824) }\end{array}$ & NUP 704 \\
\hline Glanidium ribeiroi Haseman, 1911 & NUP 2443; NUP 5436 \\
\hline $\begin{array}{l}\text { Hoplias aff. malabaricus (Bloch, } \\
\text { 1794) }\end{array}$ & NUP 687 \\
\hline Hypostomus myersi (Gosline, 1947) & NUP 5892; NUP 5924 \\
\hline $\begin{array}{l}\text { Odontesthes bonariensis } \\
\text { (Valenciennes, 1835) }\end{array}$ & NUP 1610 \\
\hline $\begin{array}{l}\text { Oligosarcus longirostris Menezes \& } \\
\text { Géry, } 1983\end{array}$ & NUP 721; NUP 1631 \\
\hline $\begin{array}{l}\text { Pimelodus britskii Garavello \& } \\
\text { Shibatta, } 2007\end{array}$ & NUP 1786; NUP 1826 \\
\hline Pimelodus ortmanni Haseman, 1911 & NUP 1664 \\
\hline Rhamdia branneri Haseman, 1911 & NUP 2448; NUP 2451 \\
\hline Rhamdia voulezi Haseman, 1911 & NUP 1659 \\
\hline
\end{tabular}

abundance of each food resource in each group or factor) and fidelity (the relative frequency of each food resource in each group or factor), and thus incorporates both frequency and occurrence measures, according to the formula (Dufrêne \& Legendre, 1997): IndVal $\mathrm{ij}_{\mathrm{ij}}=\mathrm{A}_{\mathrm{ij}} \mathrm{B}_{\mathrm{ij}}$ x 100, where: IndVal is the indicator value for food resource $i$ in group $j, A_{i j}$ is the relative volume of food resource $i$ in group $j$, and $B_{i j}$ is the relative frequency of food resource $i$ in group $j$. We tested the significance of the indicator value for each item with a Monte Carlo randomization procedure with 10,000 permutations (significance level $<0.05$ ). 
The trophic structure of the fish fauna was defined here by the proportion of the number and biomass of each trophic guild identified in each phase and sampling site. The data were obtained from the catch per unit of effort (CPUE), expressed as the number and weight of individuals per 1,000 $\mathrm{m}^{2}$ net in $24 \mathrm{~h}$. Significant differences in the guild trophic structure before and after the impoundment were identified using one-way analysis of similarity (ANOSIM). This analysis (one-way ANOSIM) was based on two groups defined a priori on the temporal factor (before and after impoundment). The significance level was 0.05 . Finally, we used discriminant analysis (SIMPER- similarity percentage) to determine which trophic guilds were responsible for dissimilarity between groupings (before and after impoundment) (Clarke, 1993). We used the Jaccard similarity index to discriminate the trophic structure and participation of each guild between different periods (ANOSIM and SIMPER, respectively).

The nMDS and Indval analyses were calculated using PCORD (McCune \& Mefford, 2006; Peck, 2010). PERMANOVA, ANOSIM and SIMPER were run using the software PAST (version 1.68) (Hammer et al. 2001).

\section{Results}

\section{Overall diet composition}

We analyzed 2,313 stomach contents from individuals sampled before the impoundment and 1,332 after, belonging to 22 species (Table 1), which represented about $99.8 \%$ of all individuals captured during the entire study period. Most species incorporated a wide array of resources in their diets, and few of the 22 species consumed only one type of resource. These results allowed us to group species into 10 trophic guilds: detritivores, algivores, herbivores, planktivores, aquatic insectivores, terrestrial insectivores, invertivores, carcinophages, piscivores, and omnivores. Except for the downstream site $(42 \%)$, in all other sites more than $50 \%$ of all species that occurred before and after the impoundment have changed their diets, being classified in different trophic guilds (Tables 2-5).

\section{Temporal and spatial variations in the diet}

The stress value (0.13) obtained in non-metric multidimensional scaling analysis (nMDS) gave a potentially useful 2-dimensional picture, allowing the definition of two groups with reduced data dimensionality (before and after impoundment). The analysis recommended three dimensions to explain the majority of variance (87\%) among food resources. However, the best dimensionality was represented by the first and second dimensions (Fig. 2). The first dimension (48\% variance) gradient contrasted aquatic plants, detritus/ sediment and algae versus fish consumption, primarily by detritivorous species and piscivorous species, respectively. Concomitantly, the second and third dimensions $(23 \%$ and $16 \%$ variances) contrasted the resources that are usually available in the benthos, such as aquatic plants, decapods, and macroinvertebrates, versus planktonic resources such as microcrustaceans and algae that were consumed after the impoundment. Plants (aquatic and terrestrial), insects (aquatic and terrestrial) and invertebrates grouped together in the multivariate space were derived from the consumption of these resources by species with more generalized diets and omnivores. The results of the two-way PERMANOVA showed that there was no significant interaction between sites and sampling periods $(\mathrm{F}=-0.72 ; \mathrm{p}=0.58)$, but indicated that the fish before and after the impoundment had significantly different diets $(F=8.72 ; \mathrm{p}=0.0001)$. This result may explain the relationships among objects displayed in the 2-D plot. Piscivorous and detritivorous species did not change their diets, regardless of the impoundment phase. The other species showed varying levels of changes in the diet (see Tables 2-5).

Different indicator food resources (IndVal) corroborated the changes in the feeding composition of most species. Before the impoundment, decapods, aquatic and terrestrial insects, macroinvertebrates, and aquatic and terrestrial plants contributed significantly to the diets of the fish. In contrast, after the impoundment, there were fewer indicator resources, all of autochthonous origin: algae, microcrustaceans and fish (IndVal; Table 6).

\section{Variation in the abundance of the trophic guilds}

The proportion of the trophic guilds showed marked spatial and temporal variation (Fig. 3). Before the impoundment, herbivores and piscivores predominated in all sampling sites, in number and biomass, respectively. After the impoundment, the abundance of herbivores decreased (except for site 4) and piscivores increased, with marked increases in biomass, especially at site 3 (dam) (Fig. 3). The ANOSIM showed significant differences in the proportions of the trophic guilds before and after the impoundment, in both number (R: 0.8021; $\mathrm{p}=0,026)$ and biomass (R: $0.8021 ; \mathrm{p}=$ $0,034)$. The SIMPER analysis also showed that abundance in terms of number and biomass were dissimilar $(70.76 \%$ and $54.28 \%$, respectively) before and after the impoundment. The trophic guilds that contributed to the differences were herbivores and piscivores, which accounted for more than $72.9 \%$ and $64.2 \%$ (number and biomass, respectively) of the differences between the periods (Table 7). Also, we recorded a reduction of the terrestrial insectivores and invertivores, and the disappearance of carcinophages from the reservoir sites. Algivores and planktivores were present only after the impoundment (Fig. 3; Table 7). 


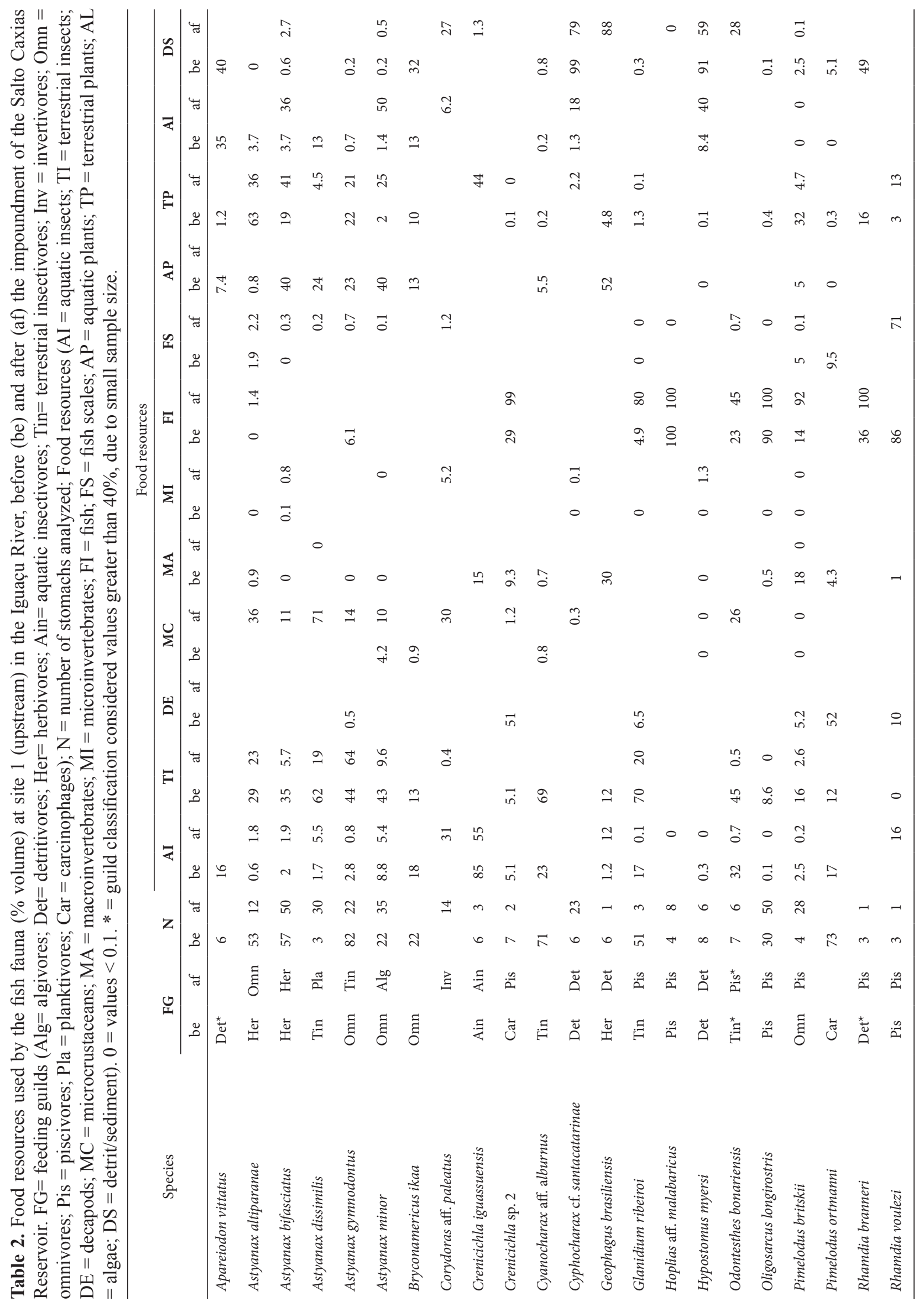




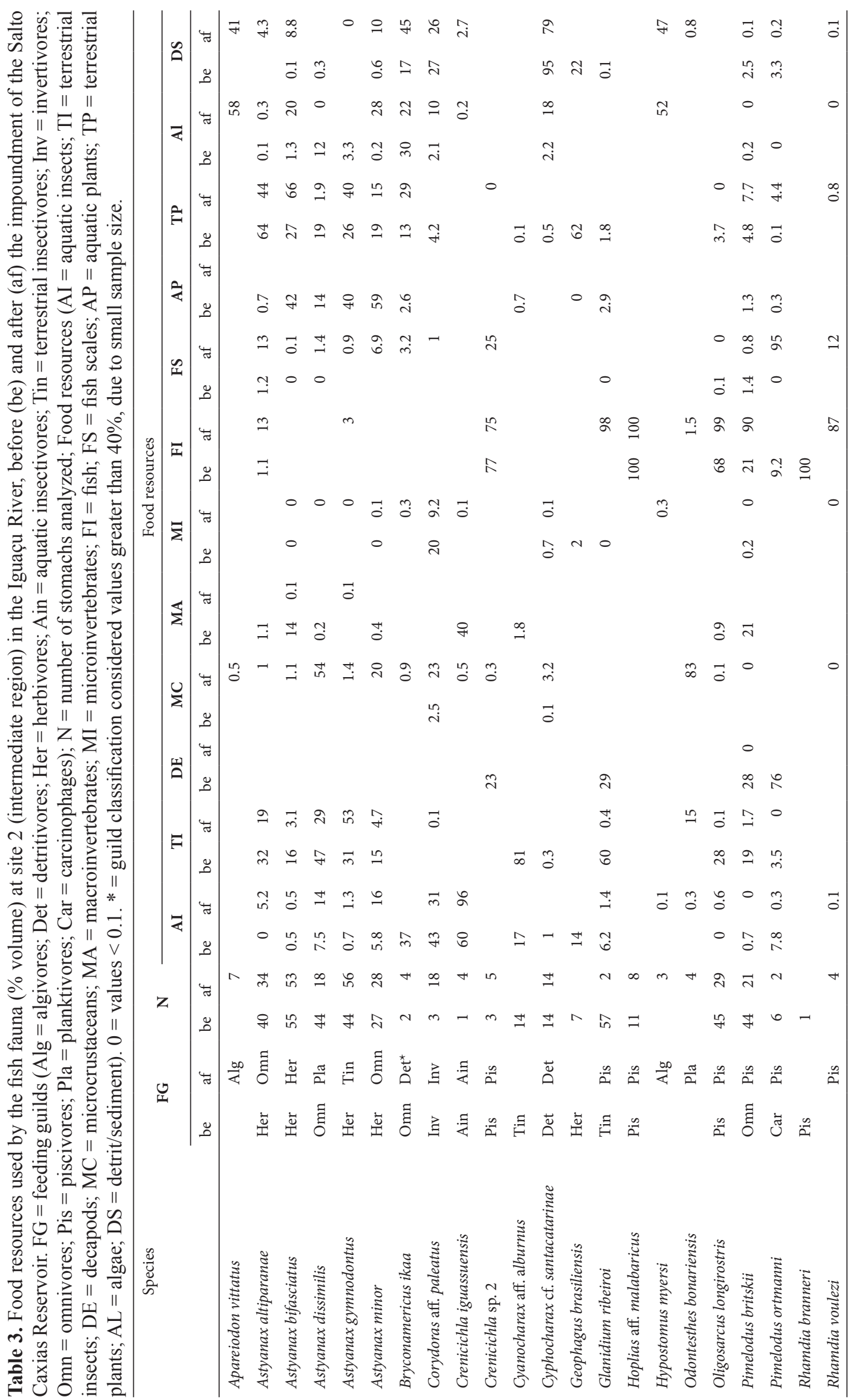




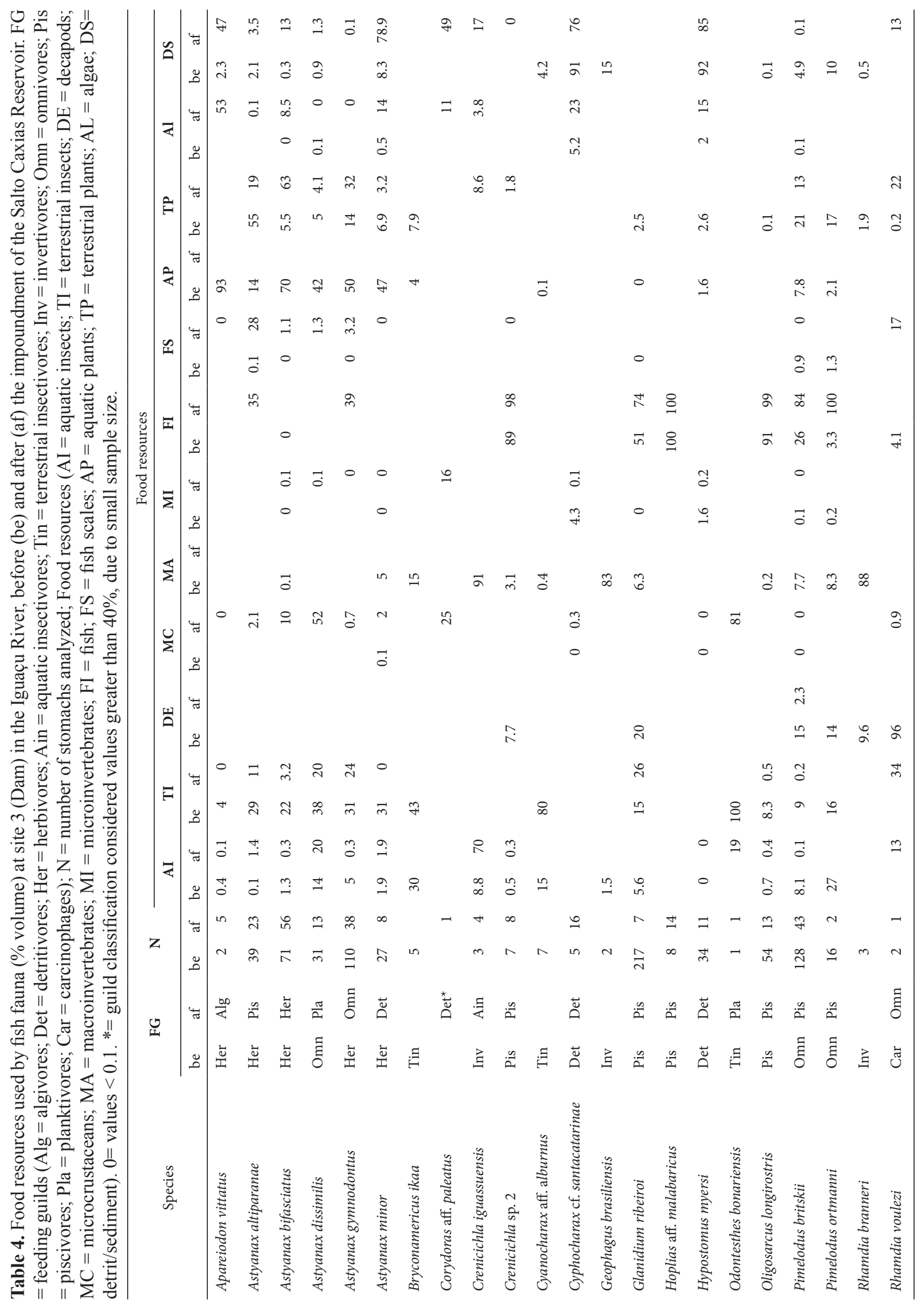




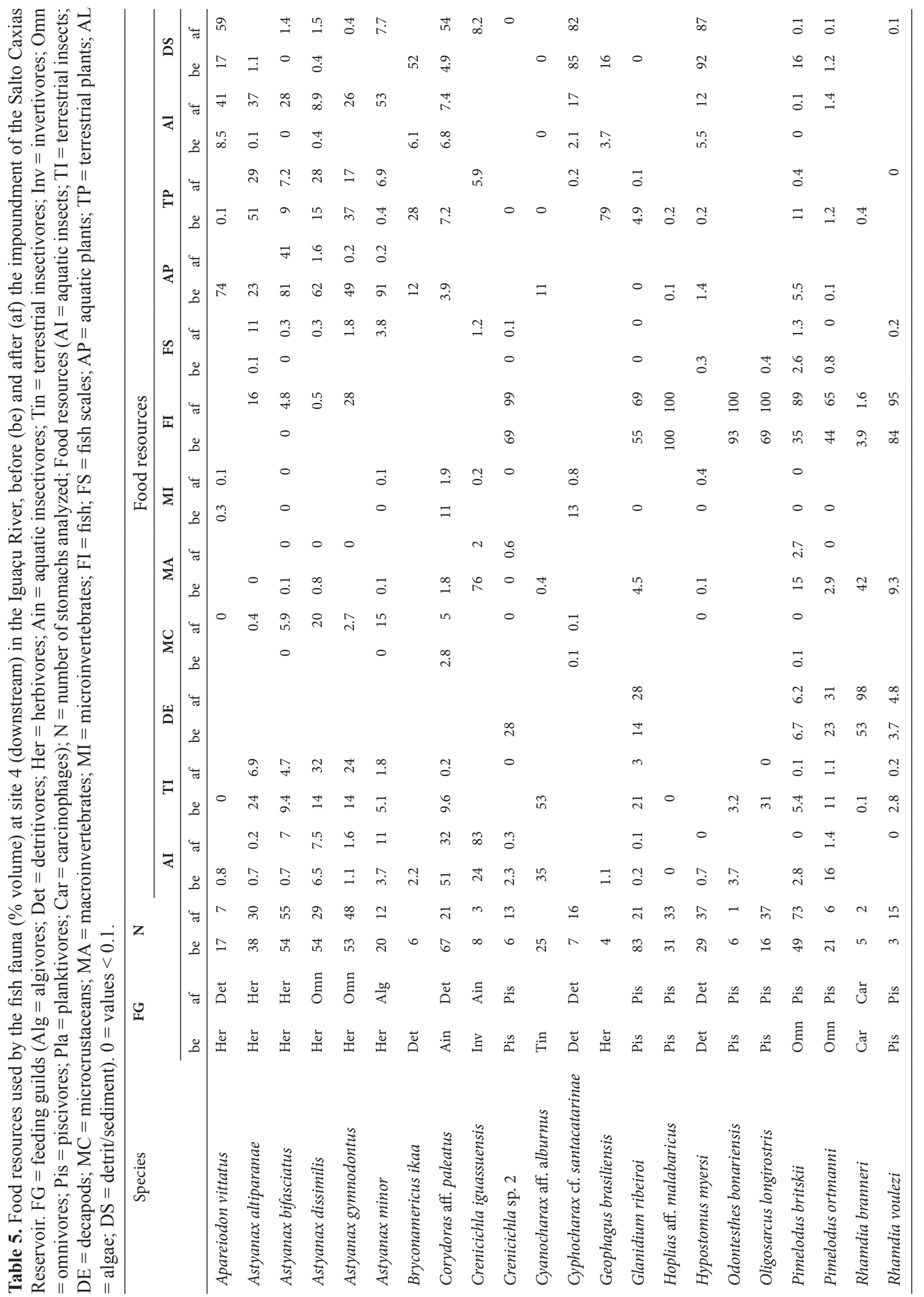


Table 6. Summary of the indicator species analysis showing the Relative Abundances (RA), Relative Frequencies (RF) and indicator values (IndVal) of food resources used by the fish fauna, before and after the impoundment of the Salto Caxias Reservoir, Iguaçu River (only food resources with significant values are listed). Bold font indicates significant indicator values $(\mathrm{p}<0.05$, Monte Carlo permutation test).

\begin{tabular}{|c|c|c|c|c|c|c|c|}
\hline \multirow[t]{3}{*}{ Food resources } & \multicolumn{2}{|c|}{ Relative abundance } & \multicolumn{2}{|c|}{ Relative Frequency } & \multicolumn{2}{|c|}{ IndVal } & \multirow[b]{3}{*}{$p$} \\
\hline & & & & & & & \\
\hline & Before & After & Before & After & Before & After & \\
\hline Terrestrial insects & 79 & 21 & 65 & 47 & 51 & 10 & 0.0001 \\
\hline Aquatic insects & 77 & 23 & 65 & 57 & 50 & 13 & 0.0001 \\
\hline Aquatic plants & 98 & 2 & 42 & 2 & 41 & 0 & 0.0001 \\
\hline Terrestrial plants & 65 & 35 & 53 & 45 & 35 & 16 & 0.0022 \\
\hline Macroinvertebrates & 92 & 8 & 19 & 6 & 18 & 0 & 0.0001 \\
\hline Decapods & 75 & 25 & 15 & 6 & 11 & 2 & 0.0059 \\
\hline Microcrustaceans & 9 & 91 & 5 & 43 & 0 & 39 & 0.0001 \\
\hline Algae & 26 & 74 & 27 & 43 & 7 & 32 & 0.0001 \\
\hline Fish & 39 & 61 & 23 & 40 & 9 & 24 & 0.0004 \\
\hline Fish scales & 36 & 64 & 16 & 36 & 6 & 23 & 0.0001 \\
\hline
\end{tabular}

Table 7. Results of the SIMPER analyses for the dissimilarity of the proportion in number and biomass (CPUE) of the trophic guilds along the longitudinal gradient of the Salto Caxias Reservoir, Iguaçu River, before and after the impoundment. (Alg = algivores; Det $=$ detritivores; Her = herbivores; Ain = aquatic insectivores; Tin = terrestrial insectivores; Inv = invertivores; $\mathrm{Omn}=$ omnivores; $\mathrm{Pis}=$ piscivores; $\mathrm{Pla}=$ planktivores; $\mathrm{Car}=$ carcinophages $)$.

\begin{tabular}{|c|c|c|c|c|c|c|}
\hline & \multirow[t]{2}{*}{ Guilds } & \multirow{2}{*}{$\begin{array}{c}\text { Average } \\
\text { dissimilarity }\end{array}$} & \multirow{2}{*}{$\begin{array}{c}\text { Contribution } \\
\%\end{array}$} & \multirow{2}{*}{$\begin{array}{c}\text { Cumulative } \\
\text { Contribution \% }\end{array}$} & \multicolumn{2}{|c|}{ Mean abundance } \\
\hline & & & & & Before & After \\
\hline & Her & 35.8 & 50.6 & 50.6 & 220.0 & $2,200.0$ \\
\hline & Pis & 15.8 & 22.3 & 72.9 & 78.6 & 490.0 \\
\hline Individuals & Omn & 6.1 & 8.7 & 81.7 & 51.1 & 201.0 \\
\hline Number & Det & 4.8 & 6.8 & 88.5 & 44.6 & 182.0 \\
\hline \multirow[t]{9}{*}{$(70.76)$} & Tin & 2.5 & 3.5 & 92.0 & 30.7 & 15.2 \\
\hline & Alg & 2.1 & 2.9 & 94.9 & 0.0 & 68.3 \\
\hline & Pla & 1.7 & 2.5 & 97.4 & 0.0 & 29.4 \\
\hline & Ain & 1.3 & 1.9 & 99.3 & 20.5 & 3.4 \\
\hline & Inv & 0.3 & 0.5 & 99.8 & 2.5 & 4.3 \\
\hline & $\mathrm{Car}$ & 0.2 & 0.2 & 100 & 1.8 & 1.9 \\
\hline & Pis & 26.0 & 47.8 & 47.8 & 7.1 & 30.0 \\
\hline & Her & 8.9 & 16.4 & 64.2 & 4.1 & 12.9 \\
\hline & Det & 8.7 & 16.0 & 80.2 & 3.5 & 9.6 \\
\hline Biomass & Omn & 4.7 & 8.6 & 88.9 & 4.0 & 1.8 \\
\hline \multirow{6}{*}{$(54.28)$} & Alg & 3.5 & 6.4 & 95.3 & 0.0 & 1.5 \\
\hline & $\mathrm{Pla}$ & 0.8 & 1.6 & 96.9 & 0.0 & 0.3 \\
\hline & Tin & 0.7 & 1.3 & 98.2 & 0.4 & 0.2 \\
\hline & $\mathrm{Car}$ & 0.5 & 0.9 & 99.1 & 0.2 & 0.3 \\
\hline & Ain & 0.2 & 0.5 & 99.6 & 0.2 & 0.1 \\
\hline & Inv & 0.2 & 0.4 & 100 & 0.1 & 0.0 \\
\hline
\end{tabular}




\section{Discussion}

In Salto Caxias Reservoir, the fish fauna appears to have used all possible compartments of the habitat, because the fish showed versatility in exploiting about 11 different types of food resources. Most species analyzed in this study exhibited marked changes in their diets after the impoundment, being classified in different trophic guilds. Although food availability has not been measured, we presume that the fish are the best samplers of the available resources (or at least those that are used) because they focus on the resource that they can effectively access (Mérona et al., 2003). The strategy of using the available resources (opportunistic sensu Gerking, 1994), is essential to allow the species to persist in impounded environments, because it enables them to broaden their range of resources and thereby tolerate more-severe impacts.

The species whose diets were least affected by the environmental changes were the typical detritivores and piscivores. Similar findings have been reported in other reservoirs (Mérona et al., 2001; Novaes et al., 2004; Fugi et al., 2005; Loureiro-Crippa \& Hahn, 2006; Luz-Agostinho et al., 2006; Pacheco et al., 2008). Detritivores and piscivores are trophic specialists with morphological adaptations of the mouth and digestive tract that may prevent them from using other resources. In addition, they may initially benefit from the high availability of detritus and fish after the impoundment (Luz-Agostinho et al., 2006; Hahn \& Fugi, 2007; Novakowski et al., 2007; Agostinho et al., 2008; Bennemann et al., 2011).

The more-pronounced changes in the diet of most species were mainly related to the temporal factor, and reflected a trend commonly recorded after the formation of reservoirs, i.e., a reduction in the intake of benthic invertebrates and allochthonous resources such as terrestrial plants and insects, which are usually replaced by resources from the reservoir environment itself, such as algae, microcrustaceans, and small-sized fish (Mérona et al., 2003; Agostinho et al., 2007; Mérona \& Vigouroux, 2012). In the pre-impoundment phase, few species exploited these resources exclusively, but they were part of the diets of almost all the species. The amounts of these food categories increase in reservoirs because of the greater supply of nutrients, which increases the overall production, an event known as the trophic upsurge period (Agostinho et al., 2007; Gubiani et al., 2011). In this period, algae, microcrustaceans, and thereafter small-sized fish develop, as described by Araújo-Lima et al. (1995) and Agostinho et al. (2007) for several Neotropical reservoirs. On the other hand, the settlement of particulate matter in the impounded environments can reduce the diversity of benthic organisms (Ruiz, 1998; Mérona et al., 2001), mainly aquatic plants (bryophytes), decapods, and macroinvertebrates. In addition, the fewer indicator food resources found after the impoundment reflected and corroborate the changes in diet

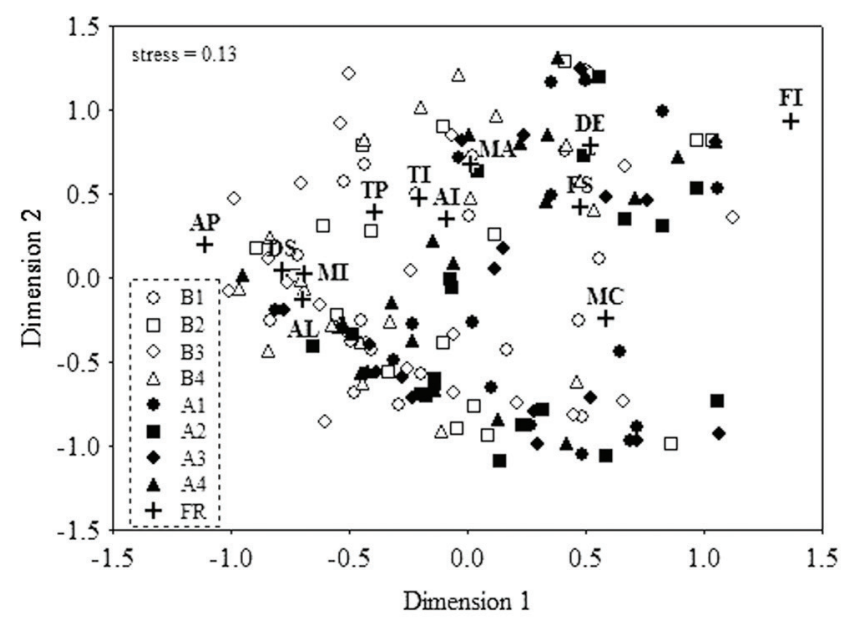

Fig. 2. Graphical representation of the first two axes of the Nonmetric multidimensional scaling (nNMDS), demonstrating the food resources used by the fish fauna in the different sites and phases, in the area influenced by the Salto Caxias Reservoir, Iguaçu River. FR $=$ Food resources $(\mathrm{AI}=$ aquatic insects; $\mathrm{TI}=$ terrestrial insects; $\mathrm{DE}=$ decapods; $\mathrm{MC}=$ microcrustaceans; $\mathrm{MA}=$ macroinvertebrates; $\mathrm{MI}=$ microinvertebrates; FI = fish; FS = fish scales; $\mathrm{AP}=$ aquatic plants; $\mathrm{TP}=$ terrestrial plants; $\mathrm{AL}=$ algae; $\mathrm{DS}=$ detrit/sediment); $\mathrm{B}=$ before impoundment, $\mathrm{A}=$ after impoundment; 1 to $4=$ sampling sites.

of the species, indicating a general trend for the fish fauna to restrict the food spectrum than in the previous phase. A similar pattern was observed by Mérona et al. (2001) in the Tocantins River, where about eight species that were formerly considered non-specialized carnivores have started consuming fish almost exclusively, and five omnivorous species changed diet to consume food of animal or vegetable origin after the reservoir was formed.

Changes in the feeding habits of the fish fauna have markedly affected the abundance of the trophic guilds, since fish species have been classified into different guilds over time and space. These alterations have affected the trophic structure, with increases in the abundance of some guilds and reductions or even the disappearance of others. These changes were observed especially at the dam and downstream, in concordance with the longitudinal zonation generally observed in reservoirs, which is usually influenced by the size and depth of the system and the residence time of the water at the different sites (Hahn et al., 1998; Agostinho et al., 1999; Araújo-Lima et al., 1995; Prchalova et al., 2009). Although this zonation is not pronounced in the Salto Caxias Reservoir, given the physiographic characteristics of the reservoir, it has developed on a smaller scale. The most striking observations were the reduction of guilds that exploit allochthonous resources and benthic organisms, and the increase of the piscivore guild. The predominance of piscivores has been recorded in many reservoirs (Petrere, 1996; Gomes \& 

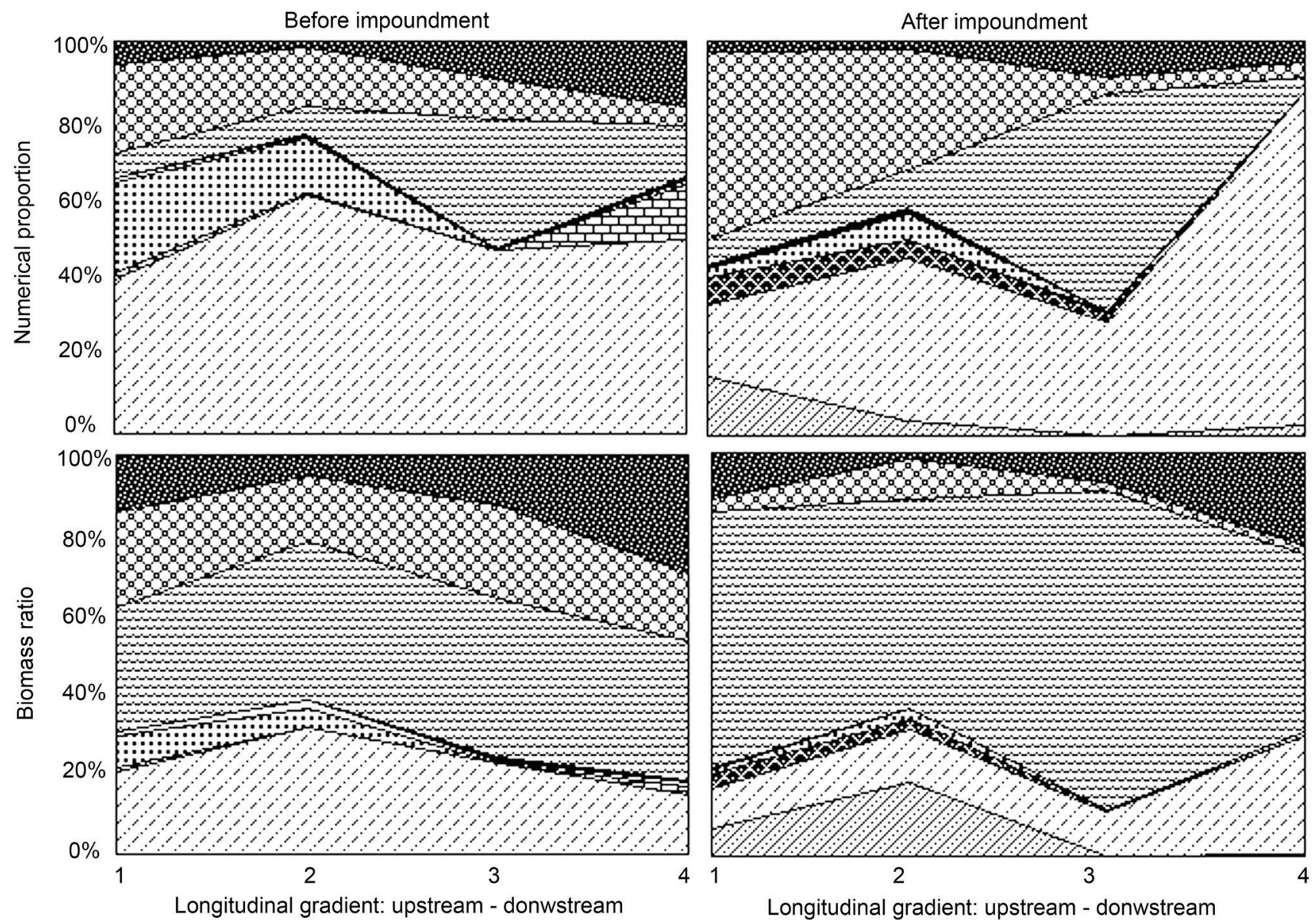

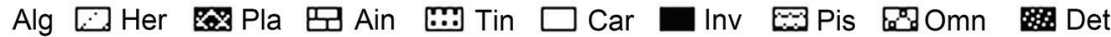

Fig. 3. Proportion in number and biomass (CPUE) of the trophic guilds along the longitudinal gradient of the Salto Caxias Reservoir, Iguaçu River, before and after the impoundment. ( 1 = upstream; $2=$ middle region; $3=$ dam; $4=$ downstream) $(\mathrm{Alg}$ $=$ algivores; Det $=$ detritivores; Her = herbivores; Ain = aquatic insectivores; Tin = terrestrial insectivores; Inv = invertivores; $\mathrm{Omn}=$ omnivores; Pis = piscivores; $\mathrm{Pla}=$ planktivores; $\mathrm{Car}=$ carcinophages $)$.

Miranda, 2001; Abelha et al., 2005; Fugi et al., 2005; Pelicice et al., 2005; Luz-Agostinho et al., 2006; Agostinho et al., 2007; Mol et al., 2007; Bennemann et al., 2011). However, in the present study, the dominance of piscivores was very high, reaching $70 \%$ of the catches in biomass and $50 \%$ in number near the dam (site 4). The large catches of Pimelodus britskii (an omnivorous fish before the impoundment) contributed to the marked dominance of piscivores, especially at the dam site. A high abundance of "lambari" (five species of Astyanax, Bryconamericus ikaa, and Cyanocharax aff. alburnus), along with other small-sized and r-strategist species, characterizes the fish fauna of the Iguaçu River (Baumgartner et al., 2012). The high intrinsic rate of population increase and the ability to quickly colonize disturbed habitats lead to a high turnover of prey individuals (Bailly et al., 2005; Fugi et al., 2005; Pelicice et al., 2005); this explains the high proportion of piscivores found in this study.
In conclusion, the present study showed evidence that the majority of species were flexible, responding almost immediately to the increase in autochthonous resources. The observed alterations in the abundance of trophic guilds were more directly related to changes in the feeding habits of the fish fauna than to increases in the number and biomass of the species that constituted these guilds. This demonstrates that the opportunistic behavior of most species influenced the community trophic structure after the impoundment. So, it corroborates our initial prediction. Additionally, this allows us to speculate that the food supply is not the major constraint impeding the initial colonization of the reservoir. Considering that the feeding strategy is one of the factors that determine the success of fish, especially in impounded environments, it is expected that those species with a more generalist diet and greater ability to exploit temporarily available resources will colonize successfully the Salto Caxias Reservoir. 


\section{Acknowledgments}

We express our appreciation to Nupélia (Núcleo de Pesquisas em Limnologia, Ictiologia e Aqüicultura) and to PEA (Programa de Pós-Graduação em Ecologia de Ambientes Aquáticos Continentais) for their financial support and infrastructure. We also thank all our colleagues for helping in the laboratory, and Jaime L. Pereira for preparing the map. The English language was revised by Janet W. Reid (JWR Associates).

\section{Literature Cited}

Abelha, M. C. F., E. Goulart \& D. Peretti. 2005. Estrutura trófica e variação sazonal do espectro alimentar da assembleia de peixes do reservatório de Capivari, Paraná, Brasil. Pp. 243252. In: Rodrigues, L., S. M. Thomaz, A. A. Agostinho \& L. C. Gomes (Eds.). Biocenoses em reservatórios: padrões espaciais e temporais. São Carlos, RIMA.

Agostinho, A.A., F. M. Pelicice \& L. C. Gomes. 2008. Dams and the fish fauna of the Neotropical region: impacts and management related to diversity and fisheries. Brazilian Journal of Biology, 68: 1119-1132.

Agostinho, A. A., F. M. Pelicice, L. C. Gomes \& H. F. Júlio Jr. 2010. Reservoir fish stocking: when one plus one may be less than two. Natureza \& Conservação, 8: 103-111.

Agostinho, A. A., L. C. Gomes \& F. M. Pelicice. 2007. Ecologia e manejo de recursos pesqueiros em reservatórios do Brasil. Maringá, EDUEM.

Agostinho, A. A., L. E. Miranda, L. M. Bini, L. C. Gomes, S. M. Thomaz \& H. I. Suzuki. 1999. Patterns of colonization in neotropical reservoirs, and prognoses on aging. Pp. 227-265. In: Tundisi, J. G. \& M. Straskraba (Eds.). Theoretical reservoir ecology and its applications. São Carlos, IIE.

Alcaraz, H. S. V., C. S. Pavanelli \& V. A. Bertaco. 2009. Astyanax jordanensis (Ostariophysi: Characidae), a new species from the rio Iguaçu basin, Paraná, Brazil. Neotropical Ichthyology, 7: $185-190$.

Alexandre, C. M. \& P. R. Almeida. 2010. The impact of small physical obstacles on the structure of freshwater fish assemblages. River Research and Applications, 26: 977-994.

Anderson, M. J. 2001. A new method for non-parametric multivariate analysis of variance. Austral Ecology, 26: 32-46.

Araújo Lima, C. A. R. M., A. A. Agostinho \& N. N. Fabré. 1995. Trophic aspects of fish communities in Brazilian rivers and reservoirs. Pp. 105-136. In: Tundisi, J. G., C. E. M. Bicudo \& T. Matsumura-Tundisi (Eds.). Limnology in Brazil. Rio de Janeiro, ABC/SBL.

Bailly, D., A. A. Agostinho, H. I. Suzuki \& E. A. Luiz. 2005. Características reprodutivas de espécies de Astyanax e sucesso na colonização de reservatórios do rio Iguaçu - PR. Pp. 243252. In: Rodrigues, L., S. M. Thomaz, A. A. Agostinho \& L. C. Gomes (Eds.). Biocenoses em reservatórios: padrões espaciais e temporais. São Carlos, RIMA.

Barletta, M., A. J. Jaureguizar, C. Baigun, N. F. Fontoura, A. A. Agostinho, V. M. F. Almeida-Val, A. L. Val, R. A. Torres, L. F. Jimenes-Segura, T. Giarrizzo, N. N. Fabré, V. S. Batista, C. Lasso, D. C. Taphorn, M. F. Costa, P. T. Chaves, J. P. Vieira \& M. F. M. Corrêa. 2010. Fish and aquatic habitat conservation in South America: a continental overview with emphasis on neotropical systems. Journal of Fish Biology, 76: 2118-2176.
Baumgartner, G., C. S. Pavanelli, D. Baumgartner, A. G. Bifi, T. Debona \& V. A. Frana. 2012. Peixes do baixo rio Iguaçu. Maringá, EDUEM.

Bennemann, S. T., W. Galves \& L. G. Capra. 2011. Recursos alimentares utilizados pelos peixes e estrutura trófica de quatro trechos no reservatório Capivara (rio Paranapanema). Biota Neotropica, 11: 64-71.

Clarke, K. R. 1993. Non-parametric multivariate analysis of changes in community structure. Australian Journal of Ecology, 18: 117-143.

Clarke, K. R. \& R. M. Warwick. 2001. Change in marine communities: an approach to statistical analysis and interpretation. $2^{\text {nd }} e d$. PRIMER-E, Plymouth.

Dias, M. S., J. F. Cornu, T. Oberdorff, C. A. Lasso \& P. A. Tedesco. 2012. Natural fragmentation in river networks as a driver of speciation for freshwater fishes. Ecography 35: 001-007.

Dufrêne, M. \& P. Legendre. 1997. Species assemblages and indicator species: the need for a flexible asymmetrical approach. Ecological Monographs, 67: 345-366.

Fièvet, É., L. T. Morais, A. T. Morais, D. Monti \& H. Tachet. 2001. Impacts of an irrigation and hydroelectric scheme in a stream with a high rate of diadromy (Guadeloupe, Lesser Antilles): Can downstream alterations affect upstream faunal assemblages? Archiv für Hydrobiologie, 3: 405-425.

Fugi, R., N. S. Hahn, V. Loureiro-Crippa \& G. C. Novakowski. 2005. Estrutura trófica da ictiofauna em reservatórios. Pp. 185195. In: Rodrigues, L., S. M. Thomaz, A. A. Agostinho \& L. C. Gomes (Eds.). Biocenoses em reservatórios: padrões espaciais e temporais. São Carlos, RIMA.

Garavello, J. C., C. S. Pavanelli \& H. I. Suzuki. 1997. Caracterização da ictiofauna do rio Iguaçu. Pp. 61-84. In: Agostinho, A. A. \& L. C. Gomes (Eds.). Reservatório de Segredo: bases ecológicas para o manejo. Maringá, EDUEM.

Gomes, L. C. \& L. E. Miranda. 2001. Factors affecting fishery yield from reservoir of the Upper Paraná River. Regulated Rivers: Research \& Management, 17: 67-76.

Gubiani, E. A., R. L. Angelini, C. G. Vieira, L. C. Gomes \& A. A. Agostinho. 2011. Trophic models in Neotropical reservoirs: testing hypotheses on the relationship between aging and maturity. Ecological Modelling, 222(23/24): 3838-3848.

Hahn, N. S. \& R. Fugi. 2007. Alimentação de peixes em reservatórios brasileiros: alterações e consequências nos estágios iniciais do represamento. Oecologia Brasiliensis, 11: 469-480.

Hahn, N. S., A. A. Agostinho, L. C. Gomes \& L. M. Bini. 1998. Estrutura trófica da ictiofauna do reservatório de Itaipu (Paraná-Brasil) nos primeiros anos de sua formação. Interciência, 23: 299-307.

Hammer, O., D. A. T. Harper \& P. D. Rian. 2001. Past: Palaeonthological statistics software package for education and data analysis. Version. 1.37. Available from: http://palaeoelectronica.org/2001_1/past/issue1_01.htm . (12 Nov 2005)

Hellawell, J. M. \& R. Abel. 1971. A rapid volumetric method for the analysis of the food of fishes. Journal of Fish Biology, 3: 29-37.

Hyslop, E. J. 1980. Stomach contents analysis: a review of methods and their application. Journal of Fish Biology, 17: 411-429.

Júlio Jr, H. F., S. M. Thomaz, A. A. Agostinho \& J. D. Latini. 2005. Distribuição e Caracterização dos Reservatórios. Pp. 1-16. In: Rodrigues, L., S. M. Thomaz, A. A. Agostinho \& L. C. Gomes (Eds.). Biocenoses em reservatórios: padrões espaciais e temporais. São Carlos, RIMA.

Júlio Jr., H. F. \& C. C. Bonecker. 1997. Reservatório de Segredo e sua inserção na bacia do rio Iguaçu. Pp. 01-17. In: Agostinho, A. A. \& L. C. Gomes (Eds.). Reservatório de Segredo: bases ecológicas para o manejo. Maringá, EDUEM. 
Kruskal, J. B. 1964. Nonmetric multidimensional scaling: a numerical method. Psychometrika 29: 115-129.

Liermann, C. R., C. Nilsson, J. Robertson \& R. Y. Ng. 2012. Implications of dam obstruction for global freshwater fish diversity. BioScience 62: 539-548.

Loureiro-Crippa, V. E. \& N. S. Hahn. 2006. Use of resources by the fish fauna of a small reservoir (Rio Jordão, Brazil) before and shortly after its filling. Neotropical Ichthyology, 4: 357-362.

Luz-Agostinho, K. D. G., L. M. Bini, R. Fugi, A. A. Agostinho \& H. F. Júlio Jr. 2006. Food spectrum and trophic structure of the ichthyofauna of Corumbá reservoir, Paraná river Basin, Brazil. Neotropical Ichthyology, 4: 61-68.

Maack, R. 1981. Geografia física do Estado do Paraná. Rio de Janeiro, Olympio.

McCune, B. \& M. J. Mefford. 2006. PC-ORD, version 5.0. Multivariate analysis of ecological data. Gleneden Beach, MjM Solfware Desing.

Mérona, B., G. M. Santos \& R. G. Almeida. 2001. Short term effects of Tucuruí Dam (Amazonia, Brazil) on the trophic organization of fish communities. Environmental Biology of Fishes, 60: 375-392.

Mérona, B., R. Vigouroux \& V. Horeau. 2003. Changes in the food resources and their utilization by fish assemblages in a large tropical reservoir in South America (Petit-Saut Dam, French Guiana). Acta Oecologica, 24: 147-156.

Mérona, B. \& R. Vigouroux. 2012. The role of ecological strategies in the colonization success of pelagic fish in a large tropical reservoir (Petit-Saut Reservoir, French Guiana). Aquatic Living Resources, 25: 41-54.

Mol, J. H., B. Mérona, P. E. Ouboter \& S. Sahdew. 2007. The fish fauna of Brokopondo Reservoir, Suriname, during 40 years of impoundment. Neotropical Ichthyology, 5: 351-368.

Novaes, J. L. C., E. P. Caramaschi \& K. O. Winemiller. 2004. Feeding of Cichla monoculus Spix, 1829 (Teleostei: Cichlidae) during and after reservoir formation in the Tocantins River. Acta Limnologica Brasiliensia, 16: 41-49.

Novakowski, G. C., N. S. Hahn \& R. Fugi. 2007. Alimentação de peixes piscívoros antes e após a formação do reservatório de Salto Caxias, Paraná, Brasil. Biota Neotropica, 7: 149-154.
Pacheco, A. C. G., M. P. Albrecht \& E. P. Caramaschi. 2008. Ecologia de duas espécies de Pachyurus (Perciformes, Sciaenidae) do rio Tocantins, na região represada pela UHE Serra da Mesa, Goiás. Iheringia, Série Zoologia, 98: 270-277.

Peck, J. E. 2010. Multivariate Analysis for Community Ecologists: Step-by-Step using PC-ORD. MjM Software Design, Gleneden Beach, Oregon.

Pelicice, F. M., F. Abujanra, R. Fugi, J. D. Latini, L. C. Gomes \& A. A. Agostinho. 2005. A piscivoria controlando a produtividade em reservatórios: explorando o mecanismo top down. Pp. $293-$ 302. In: Rodrigues, L., S. M. Thomaz, A. A. Agostinho \& L. C. Gomes (Eds.). Biocenoses em reservatórios: padrões espaciais e temporais. São Carlos, RIMA.

Petrere Jr., M. 1996. Fisheries in large tropical reservoirs in South America. Lakes and Reservoirs: Research and Management, 2: 111-133.

Piana, P. A., K. D. G. Luz, F. M. Pelicice, R. S. Costa, L. C. Gomes \& A. A. Agostinho. 2005. Predição e mecanismos reguladores da biomassa de peixes em Reservatórios. Pp. 303-310. In: Rodrigues, L., S. M. Thomaz, A. A. Agostinho \& L. C. Gomes (Eds.). Biocenoses em reservatórios: padrões espaciais e temporais. São Carlos, RIMA.

Prchalová, M., J. Kubečka, M. Čech, J. Frouzová, V. Draštík, E. Hohausová, T. Jůza, M. Kratochvíl, J. Matěna, J. Peterka, M. Říha, M. Tušer \& M. Vašek. 2009. The effect of depth, distance from dam and habitat on spatial distribution of fish in an artificial reservoir. Ecology of Freshwater Fish, 18: 247-260.

Ruiz, A. R. 1998. Fish species composition before and after construction of a reservoir on the Guadalete River (SW Spain). Archiv für Hydrobiologie, 3: 353-369.

Submitted January 2, 2013

Accepted October 8, 2013 by Fernando Pelicice

Published December 27, 2013 